\title{
Interventions to Reduce the Overuse of Imaging for Pulmonary Embolism: A Systematic Review
}

\author{
Simon Deblois, MA, MSc ${ }^{1 *}$, Carl Chartrand-Lefebvre, MD, MSc, FRCP2,3, Kevin Toporowicz, MD², \\ Zhongyi Chen², Luigi Lepanto, MD, MSc, FRCP1,3
}

${ }^{1}$ Health Technology Assessment Unit, Centre Hospitalier de I'Université de Montréal (CHUM), Montréal, Québec, Canada; ${ }^{2}$ Radiology Department, Centre Hospitalier de l'Université de Montréal (CHUM), Montréal, Québec, Canada; ${ }^{3}$ Centre de Recherche du CHUM, Centre Hospitalier de I'Université de Montréal, Montréal, Québec, Canada.

BACKGROUND: Imaging use in the diagnostic workup of pulmonary embolism (PE) has increased markedly in the last 2 decades. Low PE prevalence and diagnostic yields suggest a significant problem of overuse.

PURPOSE: The purpose of this systematic review is to summarize the evidence associated with the interventions aimed at reducing the overuse of imaging in the diagnostic workup of PE in the emergency department and hospital wards.

DATA SOURCES: PubMed, MEDLINE, Embase, and EBM Reviews from 1998 to March 28, 2017.

STUDY SELECTION: Experimental and observational studies were included. The types of interventions, their efficacy and safety, the impact on healthcare costs, the facilitators, and barriers to their implementation were assessed.

DATA SYNTHESIS: Seventeen studies were included assessing clinical decision support (CDS), educational interventions, performance and feedback reports (PFRs), and institutional policy. CDS impact was most comprehensively documented. It was associated with a reduction in imaging use, ranging from $8.3 \%$ to $25.4 \%$, and an increase in diagnostic yield, ranging from $3.4 \%$ to $4.4 \%$. The combined implementation of a CDS and PFR resulted in a modest but significant increase in the adherence to guidelines. Few studies appraised the safety of interventions. There was a lack of evidence concerning economic aspects, facilitators, and barriers.

CONCLUSIONS: A combined implementation of an electronic CDS and PFRs is more effective than purely educational or policy interventions, although evidence is limited. Future studies of high-methodological quality would strengthen the evidence concerning their efficacy, safety, facilitators, and barriers. Journal of Hospital Medicine 2018;13:52-61. (c) 2018 Society of Hospital Medicine
The last 2 decades have seen a dramatic rise in the use of medical imaging in general, ${ }^{1,2}$ as well as in the diagnostic workup of pulmonary embolism (PE) more specifically, since the introduction of multidetector row computed tomography pulmonary angiography (CTPA) in 1998. ${ }^{3}$ From 1999 to 2010, the proportions of emergency department (ED) visits associated with a diagnosis of PE and admissions for PE have increased markedly in the United States, where the situation has been well documented. ${ }^{4,5}$ A 14-fold increase in the use of CTPA was observed in health maintenance organizations from 2001 to $2008 .^{3} \mathrm{~A}$ significant increase in the probability of having a diagnosis of PE in the ED was reported, likely because of increased access to CTPA, from 2001 to $2010 .{ }^{4}$ With a prevalence of $2 \%$ or less in the ED, diagnostic yields as low as $5 \%$ suggest a significant problem of overuse. ${ }^{6,7}$

Strategies have been proposed to improve the appropriate-

\footnotetext{
*Address for correspondence and reprint requests: Simon Deblois, MA, MSc, Pavillon S, porte S05-330A, 850 rue Saint-Denis, Montréal, Québec, Canada; Telephone: 514-890-8000, ext. 36589; Fax: 514-412-7460; E-mail: simon deblois.chum@ssss.gouv.qc.ca
}

Additional Supporting Information may be found in the online version of this article.

Received: May 15, 2017; Accepted: August 3, 2017

2018 Society of Hospital Medicine DOI 10.12788/jhm.2902 ness of imaging in the detection of $\mathrm{PE}$, and these rely on the use of a validated clinical decision rule (CDR) to assess the pretest probability of the diagnosis. The purpose of this systematic review is to summarize the evidence associated with interventions aimed at reducing the overuse of imaging in the diagnostic workup of PE in the ED and hospital wards. Specifically, the types of interventions, their clinical effectiveness, as well as possible harms will be assessed. A secondary objective is to appraise the impact of these interventions on healthcare costs as well as the facilitators and barriers to their implementation.

\section{METHODS}

\section{Inclusion Criteria}

Targeted settings were EDs and inpatient services of adult tertiary and quaternary care hospitals. The search addressed interventions aimed at reducing the overuse of imaging in the diagnostic workup for PE. The comparators were usual care or another type of related intervention. The main outcomes considered were the use of imaging, diagnostic yield, radiation dose, adherence to guidelines to a quality measure, safety, and costs; both experimental and observational studies were included.

\section{Literature Search}

A systematic literature search in the following electronic databases was performed: PubMed, MEDLINE, Embase, and EBM 


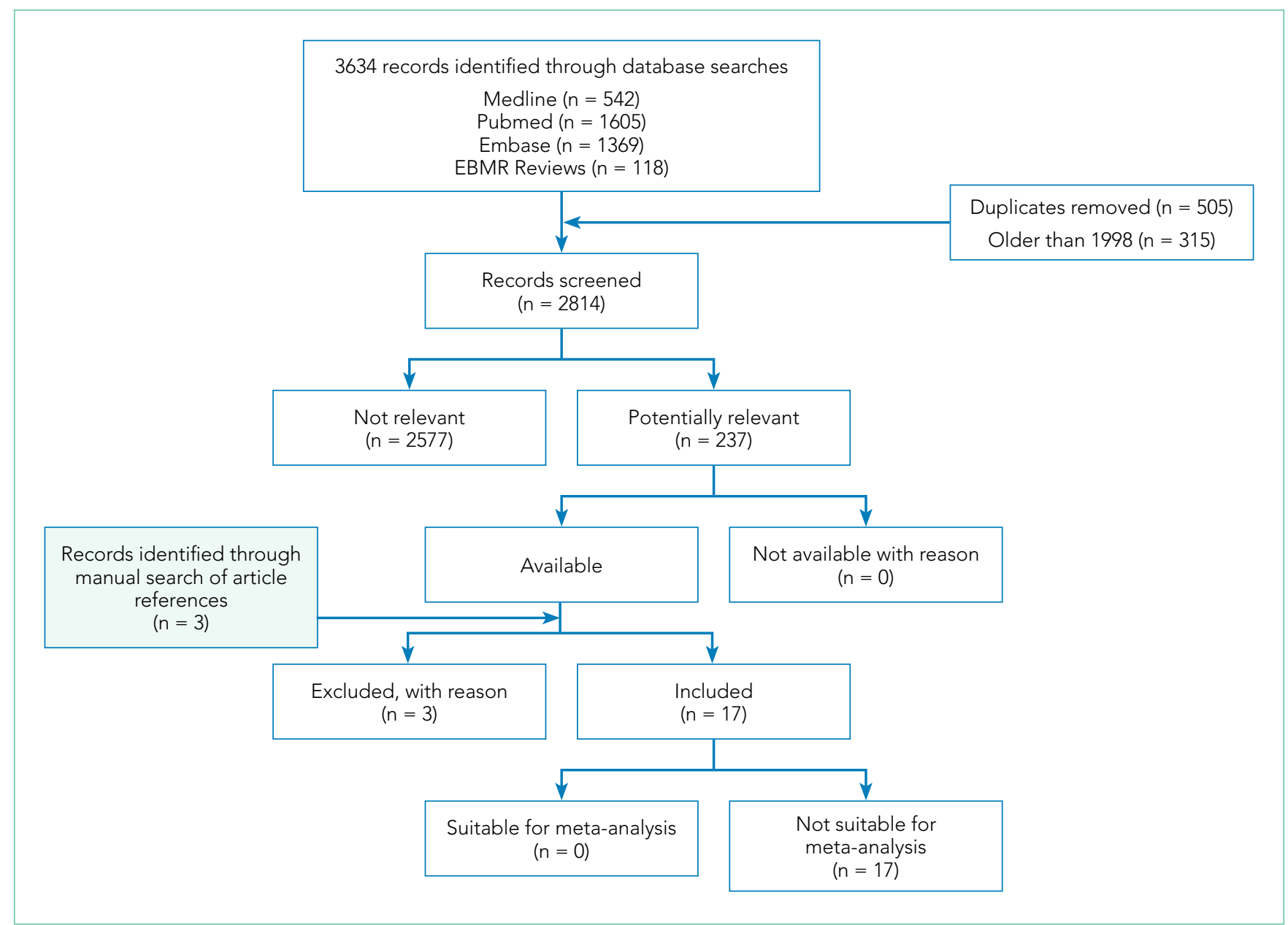

FIG. Literature selection process.

Reviews (Cochrane, ACP Journal Club, Database of Abstracts of Reviews of Effects, Cochrane Central Register of Controlled Trials, Cochrane Methodology Register, Cochrane Health Technology Assessment, and the NHS Economic Evaluation Database). The reference period was from 1998 to March 28, 2017, and publications in English and French were searched. The detailed search strategy, adapted to each of the databases, appears in supplemental Appendix 1.

\section{Study Selection and Data Extraction}

One author (SD) reviewed the titles of the selected articles and excluded those that obviously did not satisfy the inclusion criteria. Then, 2 authors (SD and LL) independently reviewed the titles and abstracts of the remaining articles. They reviewed the full manuscript of potentially relevant articles for inclusion. Disagreements that could not be resolved by discussion would have been arbitrated by a third author (CCL); however, no such disagreement occurred.

\section{Quality and Risk of Bias Assessment}

For experimental or quasiexperimental studies that involved an intervention group and a control group, the criteria proposed by the Cochrane collaborative for the evaluation of bias were used. ${ }^{8}$ For studies using a before and after design, the following main biases associated with such designs were assessed: history effect, maturation bias, testing bias, regression to the mean, and conditioning bias. ${ }^{9}$

\section{Data Extraction and Synthesis}

Data pertaining to efficacy, safety, costs, and facilitators and barriers to the implementation of interventions were extracted from the studies. The research process adhered to the Preferred Reporting Items for Systematic Reviews and Meta-Analyses 2009 checklist. ${ }^{10}$ In view of the heterogeneity of the studies, a narrative synthesis was produced in accordance with the methodology proposed by Popay et al. ${ }^{11}$ The review protocol was registered in PROSPERO (this registry can be consulted at the following URL address: http://www.crd.york. ac.uk/PROSPERO/).

\section{RESULTS}

The search screened 2814 records after the removal of duplicates and studies published before 1998. The figure illustrates the literature selection process. ${ }^{12}$ Seventeen studies were included in the review following appraisal. Most of the studies (15/17) evaluated interventions in the ED, ${ }^{7,13-26}$ while the 
TABLE 1. Characteristics of Included Studies

\begin{tabular}{|c|c|c|c|c|}
\hline Study & $\begin{array}{l}\text { Postintervention } \\
\text { Period }\end{array}$ & CDR & Setting & Expected Results \\
\hline \multicolumn{5}{|c|}{ Randomized Controlled Trials (RCT) } \\
\hline \multirow{4}{*}{$\begin{array}{l}\text { Kline et al. } \\
(2014)^{13}\end{array}$} & \multirow[t]{4}{*}{10 months } & \multirow[t]{4}{*}{ PERC and D-dimer } & \multirow{4}{*}{$\begin{array}{l}3 \text { academic ED and } 1 \\
\text { community hospital in the } \\
\text { United States }\end{array}$} & Estimated cumulative radiation dose (mSv) \\
\hline & & & & Hospital costs \\
\hline & & & & LOS \\
\hline & & & & Patient satisfaction \\
\hline \multirow{5}{*}{$\begin{array}{l}\text { Raja et al. } \\
(2015)^{14}\end{array}$} & \multirow[t]{5}{*}{12 months } & \multirow{5}{*}{$\begin{array}{l}3 \text { levels Wells criteria } \\
\text { and D-dimer }\end{array}$} & \multirow{5}{*}{$\begin{array}{l}\text { ED of a quaternary-care } \\
\text { academic hospital in the } \\
\text { United States }\end{array}$} & CTPA use ( $n$ of CTPA, $n$ of patients seen/physician) \\
\hline & & & & Yield of CTPA ( $n$ of positive exams $/ n$ of exams ordered for PE) \\
\hline & & & & Adherence to evidence-based guidelines \\
\hline & & & & Adherence to the Wells criteria \\
\hline & & & & D-dimer level \\
\hline
\end{tabular}

\section{Non-Randomized Control Study}

\begin{tabular}{|c|c|c|c|}
\hline \multirow[t]{2}{*}{ Goldstein et al. ${ }^{27} 5$ months } & \multirow[t]{2}{*}{ D-dimer } & \multirow{2}{*}{$\begin{array}{l}\text { Inpatient medical wards of } \\
\text { an academic hospital in the } \\
\text { United States }\end{array}$} & Number of imaging exams ordered \\
\hline & & & $\begin{array}{l}\text { Mortality, duration of hospitalization, and 3-month incidence of recurrent VTE or bleeding } \\
\text { complications }\end{array}$ \\
\hline
\end{tabular}

\section{"Before and After" Prospective Studies}

\begin{tabular}{|c|c|c|c|c|}
\hline \multirow[t]{3}{*}{$\begin{array}{l}\text { Kline et al. } \\
(2004)^{23}\end{array}$} & \multirow[t]{3}{*}{12 months } & \multirow[t]{3}{*}{$\begin{array}{l}\text { Charlotte rule } \\
\text { and D-dimer }\end{array}$} & \multirow[t]{3}{*}{$\begin{array}{l}\text { Large urban ED of a } \\
\text { university hospital in the } \\
\text { United States }\end{array}$} & $\begin{array}{l}\text { Presence of an adverse outcome incident within } 90 \text { days } \\
n \text { of pulmonary vascular imaging studies }\end{array}$ \\
\hline & & & & Rate of pulmonary vascular imaging (number of patients imaged/ED census) and median LOS \\
\hline & & & & Physician satisfaction \\
\hline \multirow{3}{*}{$\begin{array}{l}\text { Raja et al. } \\
(2014)^{24}\end{array}$} & \multirow[t]{3}{*}{12 months } & \multirow{3}{*}{$\begin{array}{l}3 \text { levels Wells criteria } \\
\text { and D-dimer }\end{array}$} & \multirow{3}{*}{$\begin{array}{l}\text { ED of a quaternary-care } \\
\text { academic hospital in the } \\
\text { United States }\end{array}$} & Documented adherence to the National Quality Measure (NQM) \\
\hline & & & & Utilization rate of CTPA ( $n$ of CTPA per registered number of ED patient visits) \\
\hline & & & & Yield of CTPA (proportion of all CTPA performed positive for PE) \\
\hline \multirow[t]{2}{*}{ Stein et al. ${ }^{25}$} & \multirow[t]{2}{*}{12 months } & \multirow{2}{*}{$\begin{array}{l}\text { Clinical algorithm } \\
\text { based on PIOPED || }{ }^{38}\end{array}$} & \multirow{2}{*}{$\begin{array}{l}\text { ED, radiology, and nuclear } \\
\text { medicine services of a large } \\
\text { urban academic medical } \\
\text { center in the United States }\end{array}$} & $\mathrm{n}$ and results of CTPA and V/Q scan performed quarterly \\
\hline & & & & Mean effective dose for imaging performed to evaluate suspected PE each year for each patient \\
\hline
\end{tabular}

"Before and After" Retrospective Studies

\begin{tabular}{|c|c|c|c|c|}
\hline \multirow[t]{6}{*}{ Agarwal et al. ${ }^{15}$} & \multirow[t]{6}{*}{3 months } & \multirow{6}{*}{$\begin{array}{l}3 \text { levels Wells criteria } \\
\text { and D-dimer }\end{array}$} & \multirow{6}{*}{$\begin{array}{l}\text { ED of a hospital in } \\
\text { Australia }\end{array}$} & Application of the Wells criteria (yes/no) \\
\hline & & & & Chest $x$-ray results \\
\hline & & & & Wells score \\
\hline & & & & D-dimer testing (yes/no) \\
\hline & & & & D-dimer level \\
\hline & & & & CTPA or V/Q scan result \\
\hline \multirow{6}{*}{$\begin{array}{l}\text { Booker and } \\
\text { Johnson }\end{array}$} & \multirow{6}{*}{$\begin{array}{l}2 \text { months } \\
\text { and } 24 \text { days }\end{array}$} & \multirow{6}{*}{$\begin{array}{l}\text { Dichotomous Wells } \\
\text { criteria, } 3 \text { levels Wells } \\
\text { criteria, PERC, and } \\
\text { D-dimer }\end{array}$} & \multirow{6}{*}{$\begin{array}{l}\text { ED of a community teaching } \\
\text { hospital in the United States }\end{array}$} & Age, gender, vitals on presentation \\
\hline & & & & D-dimer level \\
\hline & & & & $\begin{array}{l}\text { Signs and symptoms of DVT, immobilization or surgery within past month, history of malignancy, } \\
\text { exogenous estrogen use, hemoptysis }\end{array}$ \\
\hline & & & & Percentage of CTPA ordered with low Wells score, patients without D-dimer \\
\hline & & & & percentage of CTPA ordered on negative D-dimer \\
\hline & & & & percentage of CTPA positive for PE \\
\hline
\end{tabular}

remaining studies (2/17) were conducted in clinical wards of acute care hospitals. ${ }^{27,28}$ Thirteen studies were conducted in the United States, 3 in Australia, and 1 in Europe. Four types of interventions were identified in the selected studies: electronic clinical decision support (CDS) (8/17), educational interventions (7/17), performance feedback reports (PFRs) (1/17), and an institutional clinical pretest policy (1/17). In 10 of the studies, the proposed intervention was mandatory. 
TABLE 1. Characteristics of Included Studies (continued)

\begin{tabular}{|c|c|c|c|c|}
\hline Study & $\begin{array}{l}\text { Postintervention } \\
\text { Period }\end{array}$ & CDR & Setting & Expected Results \\
\hline Char and Yoon & 12 months & $\begin{array}{l}\text { Clinical pretest } \\
\text { (Wells criteria or other) } \\
\text { D-dimer }\end{array}$ & $\begin{array}{l}\text { ED of an HMO (Hawai) in the } \\
\text { United States }\end{array}$ & $\begin{array}{l}\text { Prevalence of PE ( } n \text { r of positive CTPA/ } n \text { of CTPA ordered for PE) } \times 100 \\
\text { Wells score } \\
\text { D-dimer level } \\
\text { Proportion of patients with D-dimer testing } \\
\text { CTPA result }\end{array}$ \\
\hline Drescher et al. ${ }^{16}$ & 4 months & $\begin{array}{l}\text { Dichotomous Wells } \\
\text { criteria and D-dimer }\end{array}$ & $\begin{array}{l}\text { ED of an academic hospital } \\
\text { in the United States }\end{array}$ & $\begin{array}{l}\text { CTPA positivity rate ([n of positive CTPA/n of CTPA ordered for PE }] \times 100) \\
\text { Order rate ([total number of CTPA/total ED visits }] \times 100) \\
\text { Patient returns within } 6 \text { months }\end{array}$ \\
\hline Dunne et al. ${ }^{28}$ & 32 months & $\begin{array}{l}3 \text { levels Wells criteria } \\
\text { and D-dimer }\end{array}$ & $\begin{array}{l}\text { Radiology department } \\
\text { and inpatient units of a } \\
\text { quaternary care academic } \\
\text { hospital in the United States }\end{array}$ & $\begin{array}{l}\text { Monthly use of CTPA/1000 admissions } \\
\text { CTPA yield (percentage of positive CTPA for PE). } \\
\text { Monthly CTPA yield before and after intervention, by clinical specialty of the ordering providers. }\end{array}$ \\
\hline Geeting et al. ${ }^{17}$ & 12 months & $\begin{array}{l}\text { Dichotomous Wells } \\
\text { criteria and D-dimer }\end{array}$ & $\begin{array}{l}\text { ED of a tertiary care } \\
\text { academic hospital in the } \\
\text { United States }\end{array}$ & $\begin{array}{l}\text { CTPA use ( } n \text { of CTPA exams and rate of study utilization [ED visits with CTPA]) } \\
\text { Appropriate CTPA use } \\
\text { CTPA overuse/underuse } \\
\text { Diagnostic yield ([n of positive CTPA studies/n of CTPA studies performed] } \times 100 \text { ) }\end{array}$ \\
\hline Goergen et al..$^{18}$ & 9 months & $\begin{array}{l}\text { Charlotte rule and } \\
\text { D-dimer }\end{array}$ & $\begin{array}{l}\text { ED of a tertiary referral } \\
\text { academic hospital } \\
\text { in Australia }\end{array}$ & $\begin{array}{l}\mathrm{n} \text { of patients with low risk and negative D-dimer diagnosed with PE or DVT during follow up } \\
\text { Proportion of patients with documented risk assessment } \\
\text { Proportion of imaged patients with low risk and negative D-dimer } \\
\text { Comparison of the proportion of patients in the study and control groups who underwent imaging of } \\
\text { any type or D-dimer assay }\end{array}$ \\
\hline Jiménez et al. ${ }^{19}$ & 12 months & $\begin{array}{l}3 \text { levels Wells criteria } \\
\text { and D-dimer }\end{array}$ & $\begin{array}{l}\text { ED of an acute care hospital } \\
\text { in Spain }\end{array}$ & $\begin{array}{l}\text { Use ( } n \text { of CTPA per } 1000 \text { ED visits) } \\
\text { Yield (percentage of CTPA positive for PE) } \\
\text { Fatal and nonfatal VTE that occurred during the 3-month follow-up period }\end{array}$ \\
\hline Kanaan et al..$^{20}$ & 26 days & $\begin{array}{l}\text { Dichotomous Wells } \\
\text { criteria or another clinical } \text { pretes }^{38-40} \\
\text { D-dimer }\end{array}$ & $\begin{array}{l}\text { ED of a tertiary care center } \\
\text { in the United States }\end{array}$ & $\begin{array}{l}\text { Sex, pregnancy status (females) } \\
\text { Result of CDR (Wells or other) } \\
\text { D-dimer result } \\
\text { Percentage with D-dimer performed before CTPA, percentage with negative D-dimer } \\
\text { Percentage with alternative explanation for chest pain } \\
\text { Imaging result (V/Q scan, CTPA or other) } \\
\text { Percentage of patients }<40 \text { years with CTV performed, prevalence rates for VTE by CTPA, any } \\
\text { changes to the patient's treatment }\end{array}$ \\
\hline Prevedello et al. ${ }^{21}$ & 18 months & $\begin{array}{l}3 \text { levels Wells criteria and } \\
\text { D-dimer }\end{array}$ & $\begin{array}{l}\text { ED of a quaternary-care } \\
\text { academic hospital in the } \\
\text { United States }\end{array}$ & $\begin{array}{l}\text { Patient age and gender } \\
\text { History of malignancy, surgery or thrombosis, and evidence of D-dimer elevation } \\
\text { Presence of PE } \\
\text { Imaging requests entered by attending physicians }\end{array}$ \\
\hline $\begin{array}{l}\text { Raja et al. } \\
(2012)^{22}\end{array}$ & 18 months & $\begin{array}{l}3 \text { levels Wells criteria and } \\
\text { D-dimer }\end{array}$ & $\begin{array}{l}\text { ED of a quaternary-care } \\
\text { academic hospital in the } \\
\text { United States }\end{array}$ & $\begin{array}{l}\text { Age, sex, date of study, history of neoplasm, VTE or recent surgery, and D-dimer level } \\
\text { Presence of PE } \\
\text { Diagnostic yield ([positive CTPA/total number of CTPA] } \times 100 \text { ) } \\
\text { Use rate ([n of CTPA performed/1000 visits to the ED] } \times 100 \text { ) }\end{array}$ \\
\hline
\end{tabular}

NOTE: Abbreviations: CDS, clinical decision support; CDR, clinical decision rule; CTPA, computed tomodensitometry pulmonary angiography; CTV, computed tomographic venography; DVT, deep vein thrombosis; ED, emergency department; HMO, health maintenance organization; LOS, length of stay; mSv, millisievert; PE, pulmonary embolism; PERC, pulmonary embolism rule-out criteria, V/Q, ventilation/perfusion; VTE, venous thromboembolism.

One systematic review and meta-analysis pertaining to the impact of CDRs on CTPA use and yield was identified. ${ }^{29}$ Five of the studies it included were also included in the present review. ${ }^{13,16,21-23}$ However, its focus is different than the present one, which aims at assessing the evidence associated with the interventions being implemented to promote the use of the CDRs. ${ }^{29}$

The list of included studies appears in supplemental Appendix 2 . The list of potentially relevant studies that were finally excluded is provided in supplemental Appendix 3. 
TABLE 2. Results Pertaining to Efficacy By Type of Intervention

\begin{tabular}{|c|c|c|c|c|c|c|c|c|c|c|}
\hline Study & \multicolumn{3}{|c|}{ Number of Participants } & Use of Imaging & $\begin{array}{c}\begin{array}{c}\text { Diagnostic } \\
\text { Yield }\end{array} \\
\\
\\
\\
\%\end{array}$ & $\begin{array}{c}P \text { and } / \text { or } \\
95 \% \mathrm{Cl}\end{array}$ & $\begin{array}{c}\text { Radiation Dose } \\
\text { mSv }\end{array}$ & $P$ and $/$ or $95 \% \mathrm{Cl}$ & $\begin{array}{c}\text { Adherence } \\
\text { to Guidelines } \\
\text { or a QM }\end{array}$ & \\
\hline
\end{tabular}

Clinical Decision Support (CDS)

\begin{tabular}{|c|c|c|c|c|c|c|c|c|c|c|c|}
\hline \multicolumn{12}{|c|}{ Voluntary Participation } \\
\hline $\begin{array}{l}\text { Drescher et } \\
\text { al. }{ }^{16}\end{array}$ & & & $\begin{array}{l}\text { Before: } 205 \\
\text { After: } 229\end{array}$ & $\begin{array}{c}\text { Before: } 14 \text { CTPA per } \\
1000 \\
\text { After: } 12.8 \text { per } 1000\end{array}$ & $\mathrm{~N} / \mathrm{A}$ & $\begin{array}{l}\text { Before: } 8.3 \\
\text { After: } 12.7\end{array}$ & $\begin{array}{l}4.9-12.9 \\
8.6-17.7\end{array}$ & & & & \\
\hline Dunne et al. ${ }^{28}$ & & & $\begin{array}{l}\text { Before: } 3037 \\
\text { After: } 2825\end{array}$ & $\begin{array}{c}\text { Before: } 26 \text { CTPA per } \\
1000 \\
\\
\text { After: } 22.8 \text { CTPA per } \\
1000\end{array}$ & .008 & $\begin{array}{l}\text { Before: } 10.4 \\
\text { After: } 12.1\end{array}$ & .65 & & & & \\
\hline $\begin{array}{l}\text { Kline et al. } \\
(2014)^{13}\end{array}$ & $\begin{array}{c}270 \\
\text { emergency } \\
\text { physicians }\end{array}$ & $\begin{array}{c}\text { Intervention: } \\
264 \\
\text { Control : } 277\end{array}$ & & & & & & $\begin{array}{l}\text { Proportion of patients } \\
\text { exposed to }>5 \mathrm{mSv} \\
\text { Intervention: } 25 \% \\
\text { Control: } 33 \%\end{array}$ & $\begin{array}{c}\text { Difference: } 8 \% ; C l \\
95 \% ; P=.038\end{array}$ & & \\
\hline $\begin{array}{l}\text { Prevedello et } \\
\text { al. } .^{21}\end{array}$ & & & $\begin{array}{l}\text { Before: } 1542 \\
\text { After: } 1349\end{array}$ & $\begin{array}{l}\text { Before: } 26.5 \text { per } 1000 \\
\text { After: } 24.3 \text { per } 1000\end{array}$ & $<.02$ & $\begin{array}{l}\text { Before: } 9.2 \\
\text { After: } 12.6\end{array}$ & $<.01$ & & & & \\
\hline $\begin{array}{l}\text { Raja et al. } \\
(2012)^{22}\end{array}$ & & & $\begin{array}{l}\text { Before: } 3855 \\
\text { After: } 2983\end{array}$ & $\begin{array}{l}\text { Before: } 14.5 \text { to } 26.4 \\
\text { per } 1000 \\
\text { (quarterly use) } \\
\text { After: } 26.4 \text { to } 21.1 \\
\text { per } 1000 \\
\text { (quarterly use) }\end{array}$ & $\begin{array}{l}<.0001 \\
.0379\end{array}$ & $\begin{array}{l}\text { Before: } 5.8 \\
\text { After: } 9.8\end{array}$ & .0323 & & & & \\
\hline \multicolumn{12}{|c|}{ Mandatory Participation } \\
\hline $\begin{array}{l}\text { Geeting et } \\
\text { al. } .^{17}\end{array}$ & & & $\begin{array}{l}\text { Before: } 1413 \\
\text { After: } 1417\end{array}$ & $\begin{array}{c}\text { Before: } 3.02 \% \\
\text { (ED visits with CTPA) } \\
\text { After: } 2.85 \% \\
\text { (ED visits with CTPA) }\end{array}$ & .13 & $\begin{array}{l}\text { Before: } 6.89 \\
\text { After: } 7.53\end{array}$ & .406 & & & $\begin{array}{l}\text { Increased from } \\
58 \% \text { (1st month) } \\
\text { to } 76 \% \text { (last } \\
\text { month) }\end{array}$ & $\mathrm{N} / \mathrm{A}$ \\
\hline $\begin{array}{l}\text { Jiménez et } \\
\text { al. }{ }^{19}\end{array}$ & & $\begin{array}{l}\text { Before: } 652 \\
\text { After: } 711\end{array}$ & & 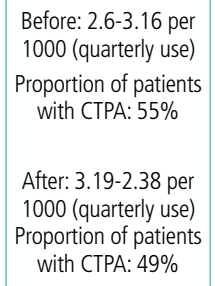 & $\begin{array}{l}.17 \\
\\
.09 \\
.02\end{array}$ & $\begin{array}{c}\text { Before: } 31 \\
\text { Quarterly yield: } \\
37.7-27.1 \\
\\
\text { After: } 33 \\
\text { Quarterly yield: } \\
26.0-46.5\end{array}$ & $<.01$ & & & & \\
\hline $\begin{array}{l}\text { Raja et al. } \\
(2014)^{24}\end{array}$ & & & $\begin{array}{l}\text { Before: } 1209 \\
\text { After: } 1212\end{array}$ & & & $\begin{array}{l}\text { Before: } 10.4 \\
\text { After: } 10.1\end{array}$ & .88 & & & $\begin{array}{l}\text { Before: } 56.9 \% \\
\text { After: } 75.6 \%\end{array}$ & $<.01$ \\
\hline
\end{tabular}

Continued on page 57

Most studies (14/17) presented a before-after design, with data collection corresponding to periods preceding and following a specific intervention. Most of them are retrospective and assessed the efficacy and safety results. They were deemed of generally poor quality and were subject to many of the biases mentioned above as well as to an interaction between the intervention and its implementation context. The remaining 3 studies were experimental in design with a comparative control group. ${ }^{13,14,27}$ In 2 of these studies, a comparison was made with traditional clinical practice (no intervention). ${ }^{13,27}$ In the third, the intervention was compared with CDS only. ${ }^{14}$ The control group studies were of intermediate to very 
TABLE 2. Results Pertaining to Efficacy By Type of Intervention (continued)

\begin{tabular}{|c|c|c|c|c|c|c|c|c|c|c|}
\hline Study & \multicolumn{3}{|c|}{ Number of Participants } & Use of Imaging & $\begin{array}{c}\begin{array}{c}\text { Diagnostic } \\
\text { Yield }\end{array} \\
\\
\\
\\
\%\end{array}$ & $\begin{array}{c}P \text { and } / \text { or } \\
95 \% \mathrm{Cl}\end{array}$ & $\begin{array}{c}\text { Radiation Dose } \\
\text { mSv }\end{array}$ & $P$ and $/$ or $95 \% \mathrm{Cl}$ & $\begin{array}{c}\text { Adherence } \\
\text { to Guidelines } \\
\text { or a QM }\end{array}$ & \\
\hline
\end{tabular}

Educational Interventions

\begin{tabular}{|c|c|c|c|c|c|c|c|c|c|}
\hline \multicolumn{10}{|c|}{ Voluntary Participation } \\
\hline $\begin{array}{l}\text { Booker and } \\
\text { Johnson }{ }^{26}\end{array}$ & $\begin{array}{l}\text { Before: } 206 \\
\text { After: } 206\end{array}$ & $\begin{array}{l}\text { Before: } 2.9 \text { CTPA } \\
\text { ordered/day } \\
\text { After: } 2.5 \text { CTPA } \\
\text { ordered/day }\end{array}$ & $\mathrm{N} / \mathrm{A}$ & $\begin{array}{l}\text { Before: } 8.7 \% \\
\text { After: } 9.2 \%\end{array}$ & .243 & & & $\begin{array}{l}\text { CTPA ordered with } \\
\text { PERC score of } 0 \\
\text { Before: } 23 \\
\text { After: } 19 \\
\text { Percentage of } \\
\text { CTPA on patient } \\
\text { with no DD and } \\
\text { low dichotomous } \\
\text { Wells score } \\
\text { Before: } 22.9 \% \\
\text { After: } 16.6 \% \\
\\
\text { Percentage of } \\
\text { CTPA on patients } \\
\text { with negative DD } \\
\text { Before: } 7.4 \% \\
\text { After: } 3.3 \%\end{array}$ & $\begin{array}{l}.15 \\
.04\end{array}$ \\
\hline $\begin{array}{l}\text { Goldstein et } \\
\text { al. }{ }^{27}\end{array}$ & $\begin{array}{l}\text { Intervention: } \\
304 \\
\text { Control: } 166\end{array}$ & $\begin{array}{c}\text { Intervention: } 11.3 \% \\
\text { Control: } 6.2 \%\end{array}$ & $<.01$ & & & & & $\begin{array}{l}\text { Intervention: DD in } \\
7.1 \% \text { of cases } \\
\text { Control: DD in } \\
2.0 \% \text { of cases }\end{array}$ & $<.01$ \\
\hline $\begin{array}{l}\text { Kanaan et } \\
\text { al. }{ }^{20}\end{array}$ & $\begin{array}{l}\text { Before: } 100 \\
\text { After: } 100\end{array}$ & & & & & & & $\begin{array}{c}\text { Before: } \\
\text { 7\% CTPA } \\
\text { studies ordered } \\
\text { appropriately } \\
\text { After: } 6 \% \text { CTPA } \\
\text { studies ordered } \\
\text { appropriately }\end{array}$ & .77 \\
\hline Stein et al. ${ }^{25}$ & $\begin{array}{l}\text { Before: } 1979 \\
\text { After: } 2136\end{array}$ & $\begin{array}{l}\text { Before: } 1.7 \text { (ratio of } \\
\text { CTPA:V/Q scanning) } \\
\text { After: } 0.8 \text { (ratio of } \\
\text { CTPA:V/Q scanning }\end{array}$ & $<.0001$ & & & $\begin{array}{c}\text { Mean effective dose: } \\
\text { Before: } 8 \mathrm{mSv} \\
\text { After: } 6.4 \mathrm{mSv}\end{array}$ & $<.0001$ & & \\
\hline
\end{tabular}

Mandatory Participation

\begin{tabular}{|c|c|c|c|c|c|c|c|c|}
\hline $\begin{array}{l}\text { Agarwal et } \\
\text { al. }{ }^{15}\end{array}$ & $\begin{array}{l}\text { Before: } 187 \\
\text { After: } 109\end{array}$ & & & & & & $\begin{array}{c}\text { Before: } 65 \% \\
\text { adherence to CPG } \\
\text { After: } 78 \% \\
\text { adherence to CPG }\end{array}$ & .017 \\
\hline $\begin{array}{l}\text { Goergen et } \\
\text { al. } .^{18}\end{array}$ & $\begin{array}{l}\text { Before: } 191 \\
\text { After: } 791\end{array}$ & & $\begin{array}{l}\text { Before: } 77 \% \\
\text { After: } 56 \%\end{array}$ & $\begin{array}{c}\mathrm{OR}=0.39 \\
(0.27-0.56) \\
\quad<.001\end{array}$ & $\begin{array}{c}\text { Before: } \\
12.04 \\
\text { After: } 9.48\end{array}$ & $\mathrm{~N} / \mathrm{A}$ & $\begin{array}{c}\text { After: } \\
62 \% \text { of ED visits } \\
\text { with documented } \\
\text { risk assessment } \\
\\
87 \% \text { of low-risk } \\
\text { and negative DD } \\
\text { with no other } \\
\text { imaging }\end{array}$ & $\mathrm{N} / \mathrm{A}$ \\
\hline $\begin{array}{l}\text { Kline et al. } \\
(2004)^{23}\end{array}$ & & $\begin{array}{l}\text { Before: } 453 \\
\text { After: } 1460\end{array}$ & $\begin{array}{l}\text { Before: } 7.4 \text { per } 1000 \\
\text { After: } 6.4 \text { per } 1000)\end{array}$ & $\begin{array}{c}\text { Difference: } \\
-1 \\
(-1.8 \text { to } 0.0)\end{array}$ & $\begin{array}{l}\text { Before: } 8.2 \% \\
\text { After: } 11.3 \%\end{array}$ & $\begin{array}{c}\text { Difference: } \\
3.0 \% \\
(-0.1 \% \text { to } 6.5 \%)\end{array}$ & & \\
\hline
\end{tabular}


TABLE 2. Results Pertaining to Efficacy By Type of Intervention (continued)

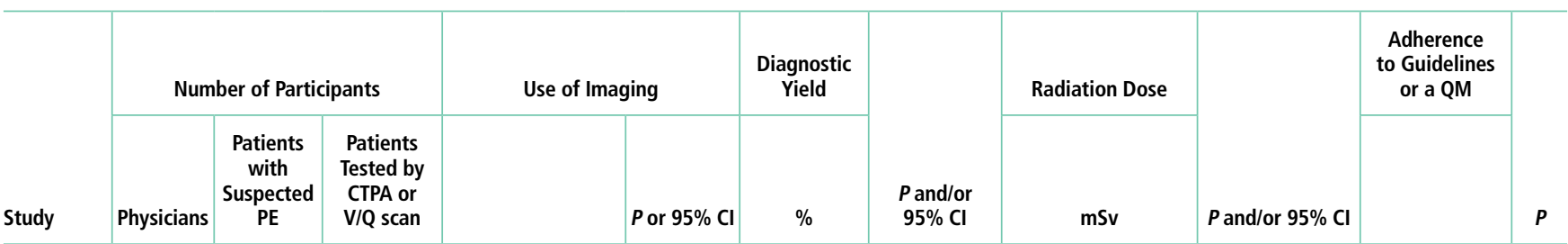

Performance and Feedback Reports (PFR) (Voluntary Participation)

\begin{tabular}{|c|c|c|c|c|c|c|c|}
\hline $\begin{array}{l}\text { Raja et al. } \\
(2015)^{14}\end{array}$ & $\begin{array}{c}\text { Intervention: } \\
22 \\
\text { Control: } 21\end{array}$ & $\begin{array}{l}\text { Intervention: } \\
\text { Before: } 20.2 \text { per } 1000 \\
\text { After: } 18.1 \text { per } 1000 \\
\\
\text { Control: } \\
\text { Before: } 20.4 \text { per } 1000 \\
\text { After: } 20.1 \text { per } 1000\end{array}$ & $\begin{array}{l}.0789 \\
\\
.8033\end{array}$ & $\begin{array}{c}\text { Intervention: } \\
\text { Before: } 11.2 \\
\text { After: } 13.1 \\
\\
\text { Control: } \\
\text { Before: } 11.6 \\
\text { After: } 11.2\end{array}$ & $\begin{array}{l}.3625 \\
\\
.8326\end{array}$ & $\begin{array}{c}\text { Intervention: } \\
\text { Before: } 78.3 \\
\text { After: } 85.2 \\
\\
\text { Control: } \\
\text { Before: } 78.8 \\
\text { After: } 77.2\end{array}$ & .5235 \\
\hline
\end{tabular}

Policy (Voluntary Participation)

\begin{tabular}{|c|c|c|c|c|c|c|c|}
\hline $\begin{array}{l}\text { Char and } \\
\text { Yoon }\end{array}$ & $\begin{array}{l}\text { Before: } 510 \\
\text { After: } 547\end{array}$ & $\begin{array}{l}\text { Before: } 15.64 \text { per } 1000 \\
\text { After: } 12.54 \text { per } 1000\end{array}$ & .01 & $\begin{array}{l}\text { Before: } 4.7 \% \\
\text { After: } 11.7 \%\end{array}$ & $<.001$ & $\begin{array}{l}\text { After: } \\
4 \% \text { of patients } \\
\text { had clinical } \\
\text { probability } \\
\text { assessment } \\
\text { recorded }\end{array}$ & $N / A$ \\
\hline
\end{tabular}

NOTE: Definitions: diagnostic yield: the percentage of examinations positive for $\mathrm{PE}$; use of imaging: the percentage of patients imaged or number of examinations for $\mathrm{PE}$ per 1000 admissions or ED patients. Abbreviations: CDR, clinical decision rule; Cl: confidence interval; CPG, clinical practice guidelines; CTPA, computed tomodensitometry pulmonary angiography; DD, D-dimer; mSv, millisievert; N/A, not available; OR, odds ratio; $\mathrm{QM}$, quality measure; $\mathrm{SD}$, standard deviation; V/Q, ventilation-perfusion.

good quality and were subject to biases of performance, detection, selection, and attrition.

Table 1 summarizes the study characteristics of the included studies. The detailed methodological quality appraisal of the control group studies appears in supplemental Appendix 4.

There is much heterogeneity in the studies, with a variety of indicators used and limited overlap in the presentation of the results. Table 2 summarizes the results pertaining to efficacy by intervention category. The baseline volume of imaging per 1000 ED admissions varied from 2.6 to $26.5 . .^{19,21}$ The diagnostic yield, measured before intervention to diminish overuse, varied from $4.7 \%$ to $31 \% .7,19$ If the European study is removed, however, the range for the baseline volume of imaging is 7.4 to 26.5 , and the diagnostic yield range is $4.7 \%$ to $12 \%{ }^{7,18,21,23}$

\section{Efficacy CDS and PFRs}

Eight of the studies appraised CDS interventions. ${ }^{13,16,17,19,21,22,24,28}$ They consisted of computer-based applications imbedded into the computerized physician order entry of the setting (ED or clinical ward of an acute care hospital), which are prompted when a physician orders an imaging exam or D-dimer test.

The implementation of electronic CDS was associated with the use of imaging, diminishing between $8.3 \%$ and $25.4 \%$ following intervention. ${ }^{19,21}$ In studies evaluating the effect of electronic CDS, a rise in diagnostic yield ranging from $3.4 \%$ to $4.4 \%^{16,21}$ and a rise in appropriate ordering ranging from $18 \%$ to $19 \%$ are also seen. ${ }^{17,24}$ One study observed a significant impact on unnecessary radiation exposure. ${ }^{13}$

In 1 study, both electronic CDS and PFRs were used together, and an increase of $8.8 \%$ was seen in appropriate ordering $(P<5) .{ }^{14}$

\section{Educational Interventions and Policy}

Seven of the interventions assessed in the included studies were educational in their essence, involving training sessions aimed at strengthening physician use of CDRs for the diagnosis of PE. ${ }^{15,18,20,23,25-27}$ Three studies observed a statistically significant impact on the compliance to clinical guidelines postintervention. 15,26,27 Two studies observed a statistically significant decrease in imaging use. ${ }^{18,23}$ One study noticed an increase in diagnostic yield postintervention. ${ }^{23}$ One study observed a significant impact on radiation exposure. ${ }^{25}$

The impact of a policy fostering the use of a CDR and D-dimer was appraised in 1 study. ${ }^{7}$ This intervention translated into a significant reduction of CTPA use and a significant increase of CTPA diagnostic yield. However, only $4 \%$ of patient charts reported a clinical probability of $\mathrm{PE}$, and in most cases, the type of CDR used was not mentioned.?

\section{Safety}

A minority of studies evaluated the safety of the interventions. ${ }^{13,18,19,23,25,27}$ Only 2 of these studies involved comparison with a control group..$^{13,27}$ Although the studies differed in study designs and evaluated different interventions in different contexts, limiting the ability to arrive at general conclusions, there was no increase in mortality and complications associated with the interventions.

The 2 studies involving a control group did not find significant differences between the intervention and the control groups with respect to mortality, complications because of thromboembolic and bleeding events, or any other adverse event during the 3-months' follow-up. ${ }^{13,27}$

Jiménez et al. ${ }^{19}$ reported less than $1 \%$ mortality following the implementation of a CDS $(0.7 \%$; $95 \% \mathrm{Cl}, 0.2 \%-1.1 \%)$. In 
their study assessing the impact of an educational intervention, Kline et al. ${ }^{23}$ (2004) observed that none of the patients discharged with a fully negative Charlotte rule died suddenly and unexpectedly at 90-day follow-up. However, another educational intervention aimed at reducing ED patients' radiation exposure observed a significant increase in the 90-day all-cause mortality of patients with negative CTPA, which was associated with a decline in the 90-day mortality of patients with negative ventilation/perfusion $(\mathrm{V} / \mathrm{Q})$ scanning. ${ }^{25}$

Jiménez et al..$^{19}$ observed an absolute decrease of $2.5 \%$ in the incidence of symptomatic VTE events after the intervention ( $95 \% \mathrm{Cl}, 0.9 \%-4.6 \% ; P<.01)$. The occurrence of VTE events, including PE, reached $1 \%$ in Goergen et al. ${ }^{18}$ and $3.9 \%$ in Kline et al. ${ }^{23}$ (2004) during follow-up.

\section{Economic Aspects}

Kline et al. ${ }^{13}$ (2014) found a significant decrease in charges and estimated costs for medical care within 90 days of initial ED presentation in the patients who were investigated with CTPA in the intervention group. The median costs of medical care within 30 days of the initial ED presentation were US $\$ 1274$ in the control group and US $\$ 934$ in the intervention group $(P=.018){ }^{13}$ The median charges of medical care within 30 days of the initial ED presentation were US $\$ 7595$ in the control group and US $\$ 6281$ in the intervention group $(P=.004) .^{13}$

\section{Facilitators and Barriers}

Only 1 study appraised the reasons given by emergency physicians for not adhering to CDS recommendations. ${ }^{16}$ The reason most often given was the time needed to access and use the application, which was perceived as having a negative impact on productivity as well as a preference for intuitive clinical judgment. ${ }^{16}$ Though not the result of specific evaluation or data collection, some authors commented on the factors that may facilitate or impede the implementation of interventions to diminish the inappropriate use. ${ }^{14,20}$ Kanaan et al..$^{20}$ proposed that factors other than the knowledge of current clinical guidelines may explain CTPA use. Booker and Johnson ${ }^{26}$ suggested that the demand for rapid turnover in the ED may lead to "socalled 'blanket ordering', which attempts to reach diagnosis as quickly as possible despite cost and patient safety." Raja et al. ${ }^{14}$ (2015) suggested that the unambiguous representation of guidelines based on validated, high-quality evidence in the CDS may have improved physician adoption in their study.

\section{DISCUSSION}

\section{Efficacy}

Baseline values for the use of imaging and diagnostic yield show important variation, especially when compared with the study performed in Europe. ${ }^{19}$ In general, only a modest impact is measured with regard to a decrease in the use of imaging, an increase in diagnostic use, and adherence to validated CDRs.

Among the interventions appraised, CDS was evaluated in the largest number of included studies, and its impact has been appraised with the largest number of indicators. Among the 6 studies that assessed the impact of this type of intervention on the use of imaging, 4 observed a significant decrease of CTPA use postintervention. 19,21,22,28 None of these studies involved a control group. The 2 with CDS that had no significant impact on CT use were conducted in US EDs and were based on dichotomous Wells scores. ${ }^{16,17}$ Adherence to CDS recommendations was mandatory in 1 and voluntary in the other. ${ }^{16,17}$ The variable impact of these interventions was at least partly attributable to contextual factors. However, because of the lack of data pertaining to these factors, it is not possible to draw conclusive remarks on their effect.

The impact of CDS on diagnostic yield was mixed because 3 studies observed an increase in diagnostic yield postintervention, ${ }^{16,21,22}$ and 3 others monitored no significant impact. ${ }^{19,24,28}$ Adherence to guidelines or a quality measure was assessed in 2 studies, which reported a significant increase in appropriate ordering. ${ }^{17,24}$ Raja et al. ${ }^{24}$ (2014) observed an $18.7 \%$ increase in appropriate ordering after the implementation of a CDS from $56.9 \%$ to $75.6 \%(P<.01)$. Geeting et al. ${ }^{17}$ observed a similar increase, with appropriate ordering increasing from $58 \%$ to $76 \%$ over the duration of the intervention. However, this increase in appropriate use was not associated with a variation in CTPA use or diagnostic yield, which leads the investigators to posit that the physicians gradually inflated the Wells score they keyed into the CDS despite that no threshold Wells score was required to perform a CTPA. ${ }^{17}$

Raja et al. ${ }^{14}$ (2015) demonstrated that the implementation of performance feedback reporting, in addition to a CDS, can significantly increase adherence to CDR for the evaluation of $P E$ in the ED. Additional studies would help to better understand the potential impact of such reports on CTPA use in the diagnostic workup of PE. However, it suggests that a combination of interventions, including the implementation of a CDS, performance feedback reporting, and well-designed and specific educational interventions, may have a more significant impact than any of these types of interventions taken separately.

The impact of the educational interventions appraised in this review on the expected results is mixed, though it is difficult to compare the observed results and draw conclusive remarks, as the characteristics of the interventions and study designs are different from each other.

\section{Safety}

There is limited evidence on the safety of appraised interventions. Only 6 studies appraised venous thrombolic events or mortality. ${ }^{13,18,19,23,25,27}$ However, no adverse events were noted in those studies evaluating possible complications or missed diagnoses. Additional research is needed to confirm the safety of the interventions appraised in this systematic review.

\section{Facilitators and Barriers}

There are significant limitations with respect to the analysis of the factors that favor or impede the implementation of the interventions appraised in this review. However, 2 studies that did not meet the inclusion criteria appraised physicians' perceptions and attitudes toward prescribing imaging tests in the diagnostic workup of PE. ${ }^{31,32}$ One is Swiss ${ }^{31}$ and the other is Canadian. ${ }^{32}$ Both were conducted in the ED of academic hospitals. Rohacek et al. ${ }^{31}$ 
observed that defensive behaviors, such as "fear of missing PE," were frequent and associated with a lower probability of a positive CTPA (OR=0.36; 95\% Cl, 0.14-0.92). Ahn et al. ${ }^{32}$ concluded that, although ED physicians who participated in their survey possessed limited knowledge of radiation doses of CTPA and V/O scans, they opted for V/Q scans that emit lower radiation doses in younger patients, especially females, which may reflect efforts done in the study setting to reduce patients' radiation exposure.

There is not enough data to conclude on safety and the impact on healthcare costs.

\section{Implications for Future Research}

Future controlled studies of high methodological quality would help to better understand the effects associated with the implementation of the interventions aimed at reducing the inappropriate use of imaging in the diagnostic workup of PE. Efficacy results show that the success of the implementation of the various types of interventions is variable. This variation may be at least partly attributable to contextual factors, such as the external en-

\section{References}

1. Smith-Bindman R, Miglioretti DL, Johnson E, et al. Use of diagnostic imaging studies and associated radiation exposure for patients enrolled in large integrated health care systems, 1996-2010. JAMA. 2012;307(22):2400-2409.

2. Canadian Institute for Health Information (CIHI). Medical Imaging in Canada 2012. https://www.cihi.ca/en/mit_summary_2012_en.pdf. Accessed December 14, 2016

3. Wiener RS, Schwartz LM, Woloshin S. When a test is too good: how CT pulmonary angiograms find pulmonary emboli that do not need to be found. BMJ. 2013;347:f3368. doi:10.1136/bmj.f3368.

4. Schissler AJ, Rozenshtein A, Schluger NW, Einstein AJ. National trends in emergency room diagnosis of pulmonary embolism, 2001-2010: a cross-sectional study. Respir Res. 2015;16:44-50.

5. Minges KE, Bikdeli B, Wang $Y$, et al. National Trends in Pulmonary Embolism Hospitalization Rates and Outcomes for Adults Aged $>/=65$ Years in the United States (1999 to 2010). Am J Cardiol. 2015;116(9):1436-1442.

6. Duriseti RS, Brandeau ML. Cost-effectiveness of strategies for diagnosing pulmonary embolism among emergency department patients presenting with undifferentiated symptoms. Ann Emerg Med. 2010;56(4):321-332.e310.

7. Char S, Yoon HC. Improving appropriate use of pulmonary computed tomography angiography by increasing the serum D-dimer threshold and assessing clinical probability. Perm J. 2014;18(4):10-15

8. Higgins JP, Altman DG, Gotzsche PC, et al. The Cochrane Collaboration's tool for assessing risk of bias in randomised trials. BMJ. 2011;343:d5928. doi:10.1136/bmj.d5928

9. Champagne F, Brousselle A, Contendriopoulos AP, Hartz Z. L'analyse des effets. In: Brousselle A, Champagne F, Contandriopoulos AP, Hartz Z, editors. L'évaluation: Concepts et Méthodes 2e Edition. Montréal: Les Presses de I'Université de Montréal; 2011: 173-198.

10. Moher D, Liberati A, Tetzlaff J, Altman DG. Preferred reporting items for systematic reviews and meta-analyses: the PRISMA statement. J Clin Epidemiol. 2009;62(10):1006-1012.

11. Popay J, Roberts H, Sowden A, et al. Guidance on the Conduct of Narrative Synthesis in Systematic Reviews. Manchester, UK: ESRC Methods Programme; 2006.

12. Velasco $M$, Perleth $M$, Drummond $M$, et al. Best practice in undertaking and reporting health technology assessments. Working group 4 report. Int $J$ Technol Assess Health Care. 2002;18(2):361-422.

13. Kline JA, Jones AE, Shapiro NI, et al. Multicenter, randomized trial of quantitative pretest probability to reduce unnecessary medical radiation exposure in emergency department patients with chest pain and dyspnea. Circ Cardiovasc Imaging. 2014;7(1):66-73.

14. Raja AS, Ip IK, Dunne RM, Schuur JD, Mills AM, Khorasani R. Effects of Performance Feedback Reports on Adherence to Evidence-Based Guidelines in Use of CT for Evaluation of Pulmonary Embolism in the Emergency Department: A Randomized Trial. AJR Am J Roentgenol. 2015;205(5):936-940.

15. Agarwal A, Persaud J, Grabinski R, Rabinowitz D, Bremner A, Mendelson R. Pulmonary embolism: are we there yet? J Med Imaging Radiat Oncol. vironment, the organizational leadership and culture, or the microsystem, such as differences in care patterns. ${ }^{33-35}$ The impact of context factors on the effectiveness of the interventions should be assessed further with appropriate tools. 33,34,36

\section{CONCLUSION}

The joint use of CDS and PFRs appears more effective than the other types of intervention in reducing the inappropriate use of CTPA. However, an approach combining these with well-designed educational interventions as well as policies may be even more effective.

Future studies of high methodological quality would strengthen the evidence concerning the relative efficacy and safety of the interventions appraised, especially when various types are combined. Future research should also aim at bringing answers to the knowledge gaps related to the factors of success and barriers associated with the implementation of the interventions.

Disclosure: The authors report no conflict of interest.

2012;56(3):270-281.

16. Drescher FS, Chandrika S, Weir ID, et al. Effectiveness and acceptability of a computerized decision support system using modified Wells criteria for evaluation of suspected pulmonary embolism. Ann Emerg Med. 2011;57(6):613-621.

17. Geeting GK, Beck M, Bruno MA, et al. Mandatory Assignment of Modified Wells Score Before CT Angiography for Pulmonary Embolism Fails to Improve Utilization or Percentage of Positive Cases. AJR Am J Roentgenol. 2016;207(2):442-449.

18. Goergen SK, Chan T, de Campo JF, et al. Reducing the use of diagnostic imaging in patients with suspected pulmonary embolism: validation of a risk assessment strategy. Emerg Med Australas. 2005;17(1):16-23.

19. Jiménez $D$, Resano $S$, Otero $R$, et al. Computerised clinical decision support for suspected PE. Thorax. 2015;70(9):909-911.

20. Kanaan Y, Knoepp UD, Kelly AM. The influence of education on appropriateness rates for $\mathrm{CT}$ pulmonary angiography in emergency department patients. Acad Radiol. 2013;20(9):1107-1114.

21. Prevedello LM, Raja AS, Ip IK, Sodickson A, Khorasani R. Does clinical decision support reduce unwarranted variation in yield of CT pulmonary angiogram? Am J Med. 2013;126(11):975-981.

22. Raja AS, Ip IK, Prevedello LM, et al. Effect of computerized clinical decision support on the use and yield of CT pulmonary angiography in the emergency department. Radiology. 2012;262(2):468-474.

23. Kline JA, Webb WB, Jones AE, Hernandez-Nino J. Impact of a rapid rule-out protocol for pulmonary embolism on the rate of screening, missed cases, and pulmonary vascular imaging in an urban US emergency department. Ann Emerg Med. 2004;44(5):490-502.

24. Raja AS, Gupta A, Ip IK, Mills AM, Khorasani R. The use of decision support to measure documented adherence to a national imaging quality measure. Acad Radiol. 2014;21(3):378-383.

25. Stein EG, Haramati LB, Chamarthy M, Sprayregen S, Davitt MM, Freeman LM. Success of a safe and simple algorithm to reduce use of CT pulmonary angiography in the emergency department. AJR Am J Roentgenol. 2010;194(2):392-397.

26. Booker MT, Johnson JO. Optimizing CT Pulmonary Angiogram Utilization in a Community Emergency Department: A Pre- and Postintervention Study. J Am Coll Radiol. 2017;14(1):65-71.

27. Goldstein NM, Kollef MH, Ward S, Gage BF. The impact of the introduction of a rapid D-dimer assay on the diagnostic evaluation of suspected pulmonary embolism. Arch Intern Med. 2001;161(4):567-571.

28. Dunne RM, Ip IK, Abbett S, et al. Effect of Evidence-based Clinical Decision Support on the Use and Yield of CT Pulmonary Angiographic Imaging in Hospitalized Patients. Radiology. 2015;276(1):167-174.

29. Wang RC, Bent S, Weber E, Neilson J, Smith-Bindman R, Fahimi J. The Impact of Clinical Decision Rules on Computed Tomography Use and Yield for Pulmonary Embolism: A Systematic Review and Meta-analysis. Ann Emerg Med. 2016;67(6):693-701.

30. Prevedello LM, Raja AS, Ip IK, Sodickson A, Khorasani R. Does clinical deci- 
sion support reduce unwarranted variation in yield of $\mathrm{CT}$ pulmonary angiogram? Am J Med. 2013;126(11):975-981.

31. Rohacek M, Buatsi J, Szucs-Farkas Z, et al. Ordering CT pulmonary angiography to exclude pulmonary embolism: defense versus evidence in the emergency room. Intensive Care Med. 2012;38(8):1345-1351.

32. Ahn JS, Edmonds ML, McLeod SL, Dreyer JF. Familiarity with radiation exposure dose from diagnostic imaging for acute pulmonary embolism and current patterns of practice. CJEM. 2014;16(5):393-404.

33. Kringos DS, Sunol R, Wagner $C$, et al. The influence of context on the effectiveness of hospital quality improvement strategies: a review of systematic reviews. BMC Health Serv Res. 2015;15(277):015-0906.

34. Kaplan HC, Brady PW, Dritz MC, et al. The influence of context on quality improvement success in health care: a systematic review of the literature. Milbank Q. 2010;88(4):500-559.

35. Pernod G, Caterino J, Maignan M, Tissier C, Kassis J, Lazarchick J. D-dimer use and pulmonary embolism diagnosis in emergency units: Why is there such a difference in pulmonary embolism prevalence between the United States of America and countries outside USA? PLoS ONE. 2017;12(1):e0169268. doi:10.1371/journal.pone.0169268

36. Saillour-Glenisson F, Domecq S, Kret M, Sibe M, Dumond JP, Michel P. Design and validation of a questionnaire to assess organizational culture in French hospital wards. BMC Health Serv Res. 2016;16:491-503.

37. Kline JA, Nelson RD, Jackson RE, Courtney DM. Criteria for the safe use of D-dimer testing in emergency department patients with suspected pulmonary embolism: a multicenter US study. Ann Emerg Med. 2002;39(2):144-152.

38. Stein PD, Fowler SE, Goodman LR, et al. Multidetector computed tomography for acute pulmonary embolism. New Engl J Med. 2006;354(22):2317-2327.

39. Stein PD, Woodard PK, Weg JG, et al. Diagnostic pathways in acute pulmonary embolism: recommendations of the PIOPED II investigators. Am J Med. 2006;119(12):1048-1055.

40. Torbicki A, Perrier A, Konstantinides S, et al. Guidelines on the diagnosis and management of acute pulmonary embolism: the Task Force for the Diagnosis and Management of Acute Pulmonary Embolism of the European Society of Cardiology (ESC). Eur Heart J. 2008;29(18):2276-2315. 